\title{
Enhancement of Working Memory in Aged Monkeys by a Sensitizing Regimen of Dopamine $\mathrm{D}_{1}$ Receptor Stimulation
}

\author{
Stacy A. Castner ${ }^{2,3}$ and Patricia S. Goldman-Rakic ${ }^{\dagger}$ \\ ${ }^{1}$ Department of Neurobiology, Yale University School of Medicine, New Haven, Connecticut 06510, ${ }^{2}$ MIICR0, Inc., Chicago, Illinois 60607, and \\ ${ }^{3}$ Departments of Psychiatry and Biopharmaceutical Sciences, University of Illinois at Chicago, Chicago, Illinois 60612
}

\begin{abstract}
A natural consequence of aging is a loss of dopamine function and associated deficits in working memory in both human and nonhuman primates. Specifically, deficiency of $\mathrm{D}_{1}$ receptor signaling has been implicated in age-related cognitive decline. Here, we report that an intermittent, sensitizing regimen of the $\mathrm{D}_{1}$ dopamine agonist ABT-431 dramatically enhances working memory performance in aged rhesus monkeys, while either producing impairment or having little effect on performance in young adult monkeys. Importantly, cognitive enhancement in the aged monkeys was still evident for $>1$ year after cessation of $D_{1}$ treatment. Because intermittent exposure to low doses of amphetamine and other stimulants has been shown to enhance responsiveness to subsequent stimulant exposure, our findings suggest that sensitization of $\mathrm{D}_{1}$ signaling may provide a novel neurobiological mechanism for improving a core cognitive process in conditions in which dopamine function has deteriorated, such as in normal aging and Parkinson's disease.
\end{abstract}

Key words: spatial working memory; nonhuman primate; $\mathrm{D}_{1}$ agonist; sensitization; aging; $\mathrm{D}_{1}$ dopamine receptors

\section{Introduction}

A pronounced loss of dopamine function occurs along with the natural aging process and is associated with a decline in shortand long-term memory capacity as well as a diminished quality of life for millions of individuals (Volkow et al., 1998; Bachman and Farde, 2001; Nieoullon, 2002). Dopamine dysfunction is integrally involved in the working memory impairments prominent in Parkinson's disease (Rinne et al., 2000; Cools et al., 2002), schizophrenia (Goldberg et al., 1991; Abi-Dargham et al., 2002), Huntington's chorea (Beckman et al., 1997), and attention deficit disorder (Levy and Farrow, 2001; Nieoullon, 2002), and may even constitute a prodromal sign of Alzheimer's disease (Welsh et al., 1991). Age-related decline in dopamine and working memory are also observed in nonhuman primates and other species (Arnsten et al., 1994; Enborg et al., 1998; El-Ghundi et al., 1999; Siddiqi et al., 1999). A variety of pharmacological strategies used to ameliorate these deficits have met with limited success.

Age-dependent decline in dopamine function encompasses decreases in the density of $\mathrm{D}_{1}$ and $\mathrm{D}_{2}$ dopamine receptor protein and mRNA, among a variety of other markers of deficiency (Goldman-Rakic and Brown, 1981; de Keyser et al., 1990; Rinne et al., 1990; Bannon and Whitty, 1997; Wang et al., 1998; Ma et al., 1999; Naoi and Maruyama, 1999; Harada et al., 2002; Henby and Trojanowski, 2003). The decline in $\mathrm{D}_{1}$ receptors is signifi-

Received Aug. 28, 2003; revised Nov. 27, 2003; accepted Dec. 1, 2003.

Funding was provided in part by a grant from the National Institutes of Mental Health (MH44866). We thank Peter Vosler and Heather A. Findlay for their expert technical assistance, and Hoechst Marion Rousell (now Aventis Pharmaceuticals) for their kind gift of ABT-431.

tDeceased, July 31, 2003

Correspondence should be addressed to Dr. Stacy A. Castner, 322 South Green Street, Suite 202, Chicago, IL 60607. E-mail: scastner@miicro.com or scastner@uic.edu.

DOI:10.1523/JNEUROSCI.3987-03.2004

Copyright $\odot 2004$ Society for Neuroscience $\quad$ 0270-6474/04/241446-05\$15.00/0 cant, because stimulation of this receptor improves working memory in humans (Davidson et al., 1990; Muller et al., 1998) and dopamine-deficient monkeys (Arnsten et al., 1994; Schneider et al., 1994; Cai and Arnsten, 1997). We recently demonstrated that intermittent $\mathrm{D}_{1}$ stimulation ameliorates working memory impairments in young adult monkeys in whom $D_{1}$ receptors were experimentally downregulated by chronic haloperidol (Lidow and Goldman-Rakic, 1994; Castner et al., 2000). Remarkably, the cognitive improvement induced by this intermittent schedule persisted for $>1$ year after cessation of treatment. A restricted range for $D_{1}$ receptor stimulation has also been found for the expression of spatially tuned delay activity or memory fields, in prefrontal neurons - the physiological underpinning of spatial working memory (Sawaguchi and GoldmanRakic, 1991; Williams and Goldman-Rakic, 1995). These studies suggest that either too much or too little $\mathrm{D}_{1}$ stimulation can lead to impairments in spatial working memory (Lidow et al., 1998).

Whereas sensitization is readily produced in rats, monkeys, and humans by psychomotor stimulants such as amphetamine (Robinson and Becker, 1986; Kalivas and Stewart, 1991; Sax and Strakowski, 1998; Castner and Goldman-Rakic, 1999), there is also evidence that it can be induced by intermittent $D_{1}$ agonist exposure in rats and monkeys (Pierce et al., 1996; Castner et al., 2000). Moreover, $D_{1}$ receptor stimulation has also been implicated in cocaine craving (Giardina and Williams, 2001), and is required for the induction of amphetamine-induced behavioral and neurochemical sensitization (Stewart and Vezina, 1989; Bjijou et al., 1996; Vezina, 1996). Thus, the mechanisms by which intermittent $D_{1}$ stimulation restored cognitive function in a chronic haloperidol-induced $\mathrm{D}_{1}$-downregulated state might be akin to those involved in the process of sensitization to psychomotor stimulants. Therefore, we examine here whether this 
process might be exploited for the treatment of endogenous dopamine deficiency in age-related cognitive decline.

\section{Materials and Methods}

Subjects. Cognitive performance was measured throughout the study in four aged $(20-30+$ years of age) and three young (7-10 years of age) female rhesus monkeys (Macaca mulatta). Males were not included in the study because of the limited availability of aged males. Monkeys were housed individually and maintained in accordance with Yale Animal Use and Care Committee and federal guidelines for the care of nonhuman primates. All of the monkeys received either a full bowl or a maintenance number of biscuits sufficient to maintain their normal body weight, as well as fruit and peanuts each day. On the basis of the medical histories available for the animals included in the present study, none of the subjects was directly related (i.e., siblings, parents, etc.). It should be noted that three of the four aged monkeys received acute low-dose drug treatments several years before the present study at various times. However, because the animals were all trained to a stable level of baseline performance before repeated $\mathrm{D}_{1}$ treatment, any previous drug experience in these monkeys should not have influenced the present results.

Spatial delayed-response task. Monkeys were trained to perform the delayed-response task, a test of spatial working memory capacity, in a Wisconsin General Testing Apparatus situated in a sound-attenuated room. In the initial training for this task, the monkey is presented with two spatially displaced wells, and the monkey watches while the experimenter baits one well; the well baited varies in a semirandom order on a trial-by-trial basis. After the well is baited, the wells are then covered with identical plaques, and an opaque screen is lowered between the experimenter and the monkey for a randomized delay (see below). During the delay, the monkey must hold in mind the spatial location of the baited well to respond appropriately and be rewarded. Task difficulty/memory load is increased by either increasing the length of delay or increasing the number of spatially displaced wells (i.e., the spatial resolution). This task involves the use of five delays that are pseudorandomly varied across trials within a given test session. Because there are 20 trials per test session, each of the five delays was tested on four trials. For a given number of wells (e.g., two-well testing board), delay lengths were defined as $0 \mathrm{~N}$, $1 N, 2 N, 3 N$, and $4 N$, where $N$ can be increased from 1 to $10 \mathrm{sec}$. Thus, in the initial training, $N=1 \mathrm{sec}$, and the five delays used across trials correspond to $0,1,2,3$, and $4 \mathrm{sec}$. Once an animal performed at $90 \%$ at $N=1, N$ was increased to 2 until $90 \%$ correct performance was achieved, and so forth, until $N=10$. If a monkey performed at an average of $90 \%$ correct across three consecutive test sessions at $N=10$, then the task was made more difficult by adding an additional well, and $N$ was lowered to $1 \mathrm{sec}$ and then increased as described above. This process continued until the animals achieved a stable level of performance as defined by $\sim 70 \pm$ $2.0 \%$ correct across a minimum of 20 consecutive test sessions (see Table 1). Throughout the $3+$ years of this study, animals were tested $3-5 \mathrm{~d}$ per week as standard in this type of longitudinal study.

$D_{1}$ agonist treatment. Once baseline performance was stable at $\sim 70 \pm$ $2.0 \%$ correct across a minimum of 20 consecutive test sessions, monkeys received intermittent treatment with the selective $D_{1}$ agonist (-)-trans 9,10-acetoxy-2-propyl-4,5,5a,6,7,11-b-hexahydro-3-thia-5-azacyclopent1-ena[c]phenanthrene hydrochloride (ABT-431; provided by Hoechst Marion Roussel, now Aventis Pharmaceuticals), which is the diacetyl prodrug of the active metabolite A-86929 to which it is hydrolyzed in vivo (Giardina and Williams, 2001). Before injection, ABT-431 was dissolved in nitrogen-percolated, double-distilled, ice-cold water under dark conditions with $0.2 \%$ ascorbic acid. Individual aliquots of $1 \mathrm{ml}$ were stored in light-protected containers at $-70^{\circ} \mathrm{C}$. During the end of the baseline testing period, the $D_{1}$ agonist period, and the early part of the post- $D_{1}$ agonist period, animals received an intramuscular injection of either drug or vehicle $30 \mathrm{~min}$ before testing. This was to ensure that the investigators were blinded to the treatment condition at all of the times, and that the monkeys were acclimated to intramuscular injections before receiving $D_{1}$ agonist treatment. No changes in gross motor behavior or alertness were observed in response to either saline or drug injections. Furthermore, no adverse consequences of repeated $D_{1}$ or saline treatment were observed in either the aged or young monkeys in the present study. The full $\mathrm{D}_{1}$ agonist ABT-431 (0.00001 or $0.0001 \mathrm{mg} / \mathrm{kg}$ ) was given weight by volume; volume of vehicle in milliliters = body weight in kilograms/10. The doses and dosing regimen used in the present study were based on our previous work with ABT-431, in which the same doses and dosing regimen reversed chronic haloperidol-induced working memory deficits (Castner et al., 2000). For the $\mathrm{D}_{1}$ agonist period, all of the monkeys received treatment with the $\mathrm{D}_{1}$ agonist for 5 consecutive days followed by a 2-3 week washout, during which time they received the vehicle alone, and this regimen (i.e., $5 \mathrm{~d}$ of $\mathrm{D}_{1}$ agonist treatment followed by a $2-3$ week washout is defined as a block) was repeated four additional times. Monkeys received five consecutive blocks of treatment. Thus, the $\mathrm{D}_{1}$ agonist period corresponded to $\sim 4$ months of testing. Note: Monkey TYR became temporarily ill during the $\mathrm{D}_{1}$ agonist period and therefore did not receive the final two blocks of treatment but was still tested in the post- $\mathrm{D}_{1}$ agonist period (see Table 1).

Data analysis. Factorial ANOVA with Scheffe post hoc comparisons was performed on the percentage (mean \pm SEM) of correct scores for each monkey for each testing period. Regression analysis (Pearson's) on the individual scores was used first to determine the stability of performance during the baseline period for the aged and young groups separately. This was then repeated across all five blocks of the $D_{1}$ agonist period and for the post- $\mathrm{D}_{1}$ agonist period for the young and aged groups separately. The values for the correlation coefficient $r$ referred to in Figure 1 were calculated from the average scores of the monkeys in each group, whereas the $r$ values in the text refer to the total data for all of the individuals. Two-way ANOVA was used to examine group (aged vs young $) \times$ condition $\left(D_{1}\right.$ agonist blocks $1-5$ in chronological order $)$ effects on the percentage of test sessions for which delayed-response performance was significantly above baseline. Three-way ANOVA was also used to examine delay $(0 N, 1 N, 2 N, 3 N$, and $4 N) \times$ group (aged vs young) $\times$ testing condition (baseline; $\mathrm{D}_{1}$ agonist period; post- $\mathrm{D}_{1}$ agonist period) effects on the mean number of errors in the task.

\section{Results}

The aged and young monkeys all met a criterion of stable baseline performance ( $\sim 70 \pm 2 \%$ correct) on delayed response for a minimum of 20 consecutive test sessions before $\mathrm{D}_{1}$ treatment (Fig. 1a) (aged, $\left.r=0.02 ; F_{(1,109)}=1.84 ; p=0.18\right)(d)$ (young, $r=$ $0.00002 ; F_{(1,90)}=0.002 ; p=0.97$ ) (note that these $r$ values pertain to the individual scores for monkeys in both groups; also see Table 1 for individual mean percent correct \pm SEM). Despite the fact that the aged monkeys tended to make more errors than young monkeys at the longest delays (see Fig. $3 a$ ), the two groups reached a comparable level of baseline performance (Fig. 1, Table 1). Significant differences in delayed-response performance of young and aged monkeys were observed, however, during the $\mathrm{D}_{1}$ agonist period. In aged monkeys, $\mathrm{D}_{1}$ agonist treatment markedly improved cognitive performance (Fig. $1 b)\left(r=0.25 ; F_{(1,202)}=\right.$ $66.12 ; p=4.216 \times 10^{-14}$ ) (Table 1$)$. Across the five blocks of $D_{1}$ treatment, the aged monkeys' performance rose by $20.22 \pm$ $3.82 \%$ compared with their mean baseline performance of $67.85 \pm 0.87 \%$ (Table 1 ). In contrast, the performance of young monkeys either showed no change $(N=1)$ or was significantly impaired $(N=2)$ in response to the same $D_{1}$ agonist regimen (Fig. 1e) $\left(r=-0.007 ; F_{(1,129)}=0.08 ; p=0.78\right)$ (Table 1). Remarkably, with each subsequent block of $D_{1}$ treatment, the aged monkeys showed increasingly extended periods of sustained cognitive improvement that extended into the washout periods between $\mathrm{D}_{1}$ agonist administrations. By the fifth $\mathrm{D}_{1}$ block, the aged monkeys exhibited a significantly greater percentage of test sessions in which their performance was above their own baseline performance compared with the young monkeys $\left(F_{(1,4)}=15.48\right.$; $p=0.0007$ ) (Fig. 2). Indeed, after the fifth and final $D_{1}$ agonist block, the performance of the aged monkeys remained improved (up to an average of $83.61 \pm 0.68$, or $23.22 \pm 1.63 \%$ improvement relative to their baseline performance) for periods of $>1$ 
year (Fig. 1c) $\left(r=0.002 ; F_{(1,329)}=1.77\right.$; $p=0.18$; no significant change in performance over time). In direct contrast, the post- $\mathrm{D}_{1}$ agonist performance of young monkeys was not significantly different from their baseline performance (mean \pm SEM, $71.47 \pm 4.71 \%$ correct during the post- $\mathrm{D}_{1}$ agonist testing period vs $72.65 \pm$ $4.41 \%$ during the baseline testing period). During the post- $\mathrm{D}_{1}$ agonist period, the cognitive improvement shown by the two previously $\mathrm{D}_{1}$-impaired young monkeys (Fig. $1 f$ ) could be attributable to the recovery from agonist-induced cognitive deficits.

There was a significant effect of delay across all of the conditions, that is, monkeys in both groups made more errors at longer delays (baseline, $F_{(4,25)}=23.23, p<$ $0.0001 ; \mathrm{D}_{1}$ agonist, $F_{(4,25)}=8.63, p=$ 0.0002 ; post- $\mathrm{D}_{1}$ agonist, $F_{(4,25)}=4.74, p=$ 0.006) (Fig. 3). However, no delaydependent effects of treatment were observed. Delay-dependent effects of age were evident during the $\mathrm{D}_{1}$ agonist and post- $\mathrm{D}_{1}$ agonist testing periods. As a group, aged monkeys made significantly fewer errors than did young monkeys at the lowest delays during the $\mathrm{D}_{1}$ agonist pe$\operatorname{riod}\left(F_{(1,1)}=12.84 ; p=0.001\right)($ Fig. $3 b)$ as well as during the post- $\mathrm{D}_{1}$ agonist period $\left(F_{(1,1)}=7.46 ; p=0.01\right)(c)$. None of the monkeys showed any change in appetite, motivation, or general activity in response to $\mathrm{D}_{1}$ agonist treatment.

\section{Discussion}

The present findings provide evidence that a short-term, intermittent regimen of $\mathrm{D}_{1}$ stimulation improves spatial working memory performance in aged monkeys in whom the dopamine system is known to be compromised, but has minimal effects in young adult monkeys with presumed normal dopamine function. This result is consistent with our previous finding that short-term $\mathrm{D}_{1}$ stimulation ameliorates working memory deficits in a chronic haloperidol-induced $\mathrm{D}_{1}$-downregulated state (Castner et al., 2000) and with previous findings on the cognitiveenhancing effects of acute $\mathrm{D}_{1}$ agonist treatment in aged monkeys and other cases of dopamine deficiency, including schizophrenia (Davidson et al., 1990; Arnsten et al., 1994; Schneider et al., 1994; Cai and Arnsten, 1997; Muller et al., 1998; Castner et al., 2000). The present study did not assess the importance of the timing of intermittency per se, but there is reason to hypothesize that this is an important element in the treatment regimen.

The progressive and long-lasting cognitive enhancement evoked by repeated, intermittent treatment with a $\mathrm{D}_{1}$ agonist in aged monkeys is reminiscent of the development of behavioral sensitization (Robinson and Becker, 1986; Kalivas and Stewart, 1991; Sax and Strakowski, 1998; Castner and Goldman-Rakic, 1999). However, as demonstrated by the lack of an observable long-term effect of $\mathrm{D}_{1}$ treatment in young monkeys, it appears that sensitization to a selective $\mathrm{D}_{1}$ agonist may require a dopamine-deficient state such as that which occurs during the natural aging process or during chronic neuroleptic treatment. In
Aged Monkeys
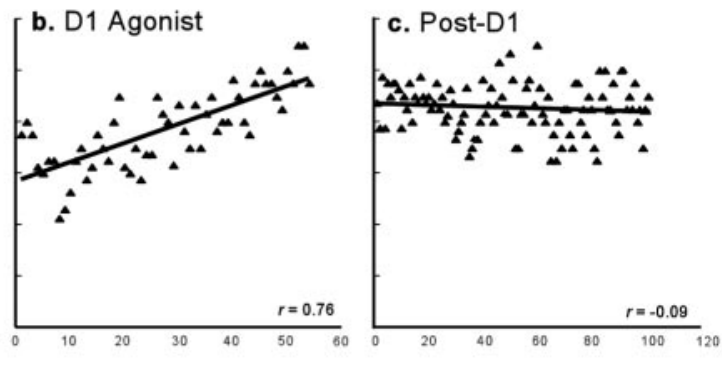

Young Monkeys
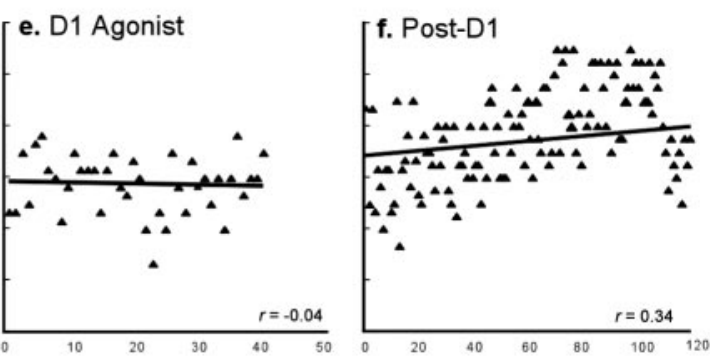

Test Sessions

Figure 1. Delayed-response performance across baseline, $D_{1}$ agonist, and post- $D_{1}$ agonist testing periods in aged and young monkeys' performance returned to baseline $(f)$. The $r$ values in the graphs are based on the mean performance for all four aged or all three young monkeys on given test sessions within each testing period.

Table 1. Individual delayed-response performance across testing conditions

\begin{tabular}{clll}
\hline Monkey & Baseline & $D_{1}$ agonist & Post- $D_{1}$ agonist \\
\hline Aged & & \\
TYR & $66.60 \pm 1.84$ & $80.00 \pm 1.89^{*}$ & $82.41 \pm 1.52^{*}$ \\
RAM & $70.48 \pm 1.58$ & $90.58 \pm 1.74^{*}$ & $93.33 \pm 1.57^{*}$ \\
SYB & $69.32 \pm 1.84$ & $75.71 \pm 2.22^{*}$ & $80.86 \pm 1.27^{* *}$ \\
AGA & $65.00 \pm 1.71$ & & \\
Young & & $70.39 \pm 1.64$ & $68.90 \pm 2.90$ \\
JOA & $69.60 \pm 2.62$ & $69.00 \pm 2.00^{*}$ & $71.00 \pm 1.99$ \\
MAR & $76.00 \pm 2.00$ & $63.43 \pm 3.31^{*}$ & $74.50 \pm 3.14^{*}$ \\
ISL & $72.35 \pm 2.50$ & & \\
\hline
\end{tabular}

Shown are the mean \pm SEM percentage correct for four aged and three young monkeys across baseline, the last two blocks of $D_{1}$ agonist treatment, and the post $-D_{1}$ period. Symbols indicate that performance under a particula condition differs significantly from another condition at an $\alpha$-level of 0.05 as indicated by factorial ANOVA with Scheffe post hoc comparisons ( ${ }^{*}$ significant versus baseline; ${ }^{*}$ significant versus $D_{1}$ agonist). Note: The blank space for monkey TYR under the $D_{1}$ agonist column reflects the fact that this monkey did not receive the final two blocks of treatment during the $D_{1}$ agonist testing period because of temporary illness. It is of note, however, that despite the abbreviated $D_{1}$ regimen in this $\geq 30$-year-old monkey, significant improvement in spatial working memory was observed during the post $-D_{1}$ agonist testing period.

fact, previous studies have shown that repeated $\mathrm{D}_{1}$ agonist exposure induces behavioral sensitization in 6-hydroxydopaminelesioned animals, in which it has been postulated that a functional uncoupling of $\mathrm{D}_{1}$ and $\mathrm{D}_{2}$ receptors underlies this effect (Criswell et al., 1989, 1990). Whether such uncoupling occurs in response to age-related dopamine decline remains to be determined. In addition to age-related cognitive decline, this therapeutic $D_{1}$ regimen has potential relevance for the treatment of cognitive deficits in other dopamine dysfunctional states such as schizophrenia, Parkinson's disease, and attention deficit disorder. 


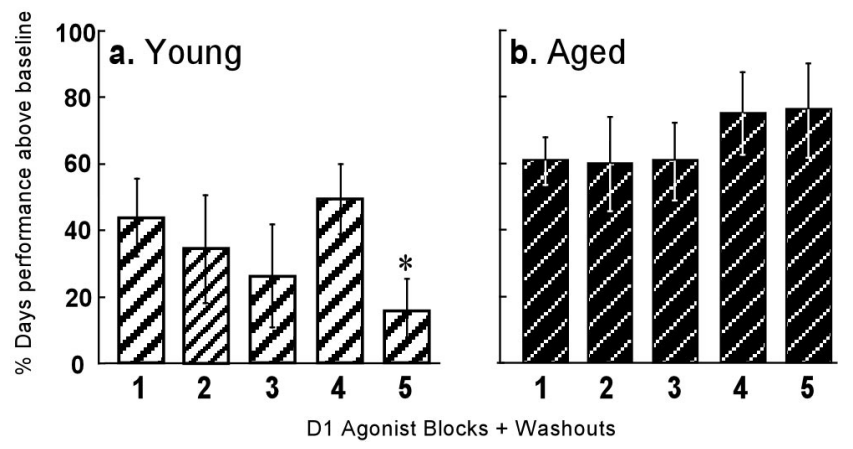

Figure 2. The percentage of days that delayed-response performance was significantly above baseline during the $D_{1}$ agonist period. For young monkeys $(a)$ and aged monkeys $(b)$, the percentage (mean \pm SEM) of test sessions in which performance was significantly above baseline for each of the five treatment blocks is shown. On the $x$-axis, the five $D_{1}$ agonist blocks (each block corresponded to $5 \mathrm{~d}$ of $\mathrm{D}_{1}$ treatment and a $2-3$ week washout period) are chronologically labeled $1-5$. The average performance of the aged monkeys was significantly improved by the fifth $\mathrm{D}_{1}$ agonist block, whereas, as a group, the young monkeys actually showed a decline in performance, as evidenced by the fact that they performed above baseline on only $<20 \%$ of test sessions for this block. *The performance of the young and aged monkeys differed significantly from one another during the fifth treatment block at an $\alpha$-level of 0.05 , as measured by two-way ANOVA with Scheffe post hoc comparisons. Error bars denote SEM.
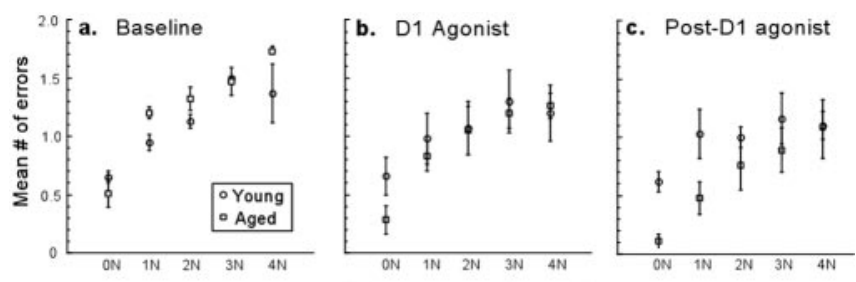

Delays seconds $(\mathrm{N}=1-10)$

Figure 3. The mean number of errors for aged and young monkeys across delays during baseline, $D_{1}$ agonist, and post- $D_{1}$ agonist testing periods. Shown are the mean number of errors \pm SEM (error bars) for aged (open squares) and young (open circles) monkeys across the five different delays ( N ranging from 1 to $10 \mathrm{sec}$ ) during baseline $(a), D_{1}$ agonist $(b)$, and post- $D_{1}$ agonist $(c)$ testing periods. There was a significant effect of delay across all of the conditions for both aged and young monkeys, that is, both groups of monkeys made significantly more errors at longer delays. As a group, aged monkeys made significantly fewer errors than did young monkeys at the lowest delays and compared with their own baseline performance during the $D_{1}$ agonist $(b)$ and post $-D_{1}$ agonist testing periods $(c)$.

The sustained enhancement in the cognitive function of aged monkeys suggests that intermittent treatment with a $D_{1}$ agonist may induce fundamental alterations in the functional circuitry that underlies working memory. These long-term changes may involve permanent alterations in the $\mathrm{D}_{1}$ signal transduction pathway. In aging, there is a significant reduction in striatum and frontal cortex in the ability of dopamine to stimulate cAMP (Puri and Volicer, 1977; Amenta et al., 1990). Given that cAMP production is elevated after repeated administration of psychomotor stimulants, such as amphetamine and cocaine, it is conceivable that enhancement of cAMP may contribute to the enduring cognitive enhancement observed in the aged monkeys in the present study. Furthermore, there is evidence that inositol 1,4,5triphosphate and calcium signaling decline as a function of aging in the rodent brain (Sandhu et al., 2001), which raises the question as to whether $D_{1}$ facilitation of this signaling via calcyon, a $\mathrm{D}_{1}$-interacting protein (Lezcano et al., 2000), is also downregulated in aging. Thus, one could hypothesize that the enduring cognitive improvement in the aged monkeys might be, at least in part, attributable to a $\mathrm{D}_{1}$-induced upregulation of signal transduction in this pathway. Morphological changes could also be involved. For example, there is evidence that repeated treatment with indirect dopamine agonists, such as amphetamine, increases the density of dendritic spines on pyramidal neurons in prefrontal cortex (Robinson and Kolb, 1999). Because $D_{1}$ receptors are preferentially localized to spines, it is possible that the improvement in spatial working memory shown by aged monkeys after repeated, intermittent $\mathrm{D}_{1}$ agonist treatment could actually reflect an upregulation of $\mathrm{D}_{1}$ receptors. Moreover, repeated stimulation of the $\mathrm{D}_{1}$ receptor can also lead to an enhancement of $\mathrm{D}_{2}$ receptor function, and $\mathrm{D}_{2}$ agonists have also been shown to improve spatial working memory in aged monkeys (Arnsten et al., 1995; Pollack and Yates, 1999). Hence, the potential contribution of enhanced signaling via $\mathrm{D}_{2}$ receptors to the present findings cannot be ruled out, although ABT-431, which is the prodrug of A-86929, has itself a low affinity at the $\mathrm{D}_{2}$ receptor (Shiosaki et al., 1996). It remains to be seen, however, to what extent the effects attributable to the repeated systemic administration of the $D_{1}$ agonist used in the present study reflect actions through the $\mathrm{D}_{5}$ versus the $\mathrm{D}_{1}$ signaling pathway. Thus, for future studies, it will be important to determine the optimal regimen of treatment and the cellular mechanisms by which repeated brief periods of $D_{1}$ agonist stimulation lead to an enduring improvement in working memory in aging. These findings are highly significant to the enhancement of cognitive function in an ever-increasing elderly population and may provide the basis for drug development targeted toward this purpose.

\section{References}

Abi-Dargham A, Mawlawi O, Lombardo I, Gil R, Martinez D, Huang Y, Hwang DR, Keilp J, Kochan L, Van Heertum R, Gorman JM, Laruelle M (2002) Prefrontal dopamine $D_{1}$ receptors and working memory in schizophrenia. J Neurosci 22:3708-3719.

Amenta F, Cavallotti C, Collier WL, De Michele M, Ricci A (1990) Agerelated changes of dopamine sensitive cyclic AMP generation in the rat frontal cortex. Mech Ageing Dev 54:63-73.

Arnsten AFT, Cai JX, Murphy BL, Goldman-Rakic PS (1994) Dopamine $\mathrm{D}_{1}$ receptor mechanisms in the cognitive performance of young adult and aged monkeys. Psychopharmacology 116:143-151.

Arnsten AFT, Cai JX, Steere JC, Goldman-Rakic PS (1995) Dopamine $\mathrm{D}_{2}$ receptor mechanisms contribute to age-related cognitive decline: the effects of quinpirole on memory and motor performance in monkeys. J Neurosci 15:3429-3439.

Bachman L, Farde L (2001) Dopamine and cognitive functioning: brain imaging findings in Huntington's disease and normal aging. Scand J Psychol 42:287-296.

Bannon MJ, Whitty CJ (1997) Age-related and regional differences in dopamine transporter RNA expression in human midbrain. Neurology 48:969-977.

Beckman I, Robins-Wahlin TB, Lundin A, Ginovart N, Farde L (1997) Cognitive deficits in Huntington's disease are predicted by dopaminergic PET markers and brain volumes. Brain 120:2207-2217.

Bjijou Y, Stinus L, Le Moal M, Cador M (1996) Evidence for selective involvement of dopamine $D_{1}$ receptors of the ventral tegmental area in the behavioral sensitization induced by intra-ventral tegmental area injections of D-amphetamine. J Pharmacol Exp Ther 277:1177-1187.

Cai JX, Arnsten AFT (1997) Dose-dependent effects of the dopamine $\mathrm{D}_{1}$ receptor agonists A77636 or SKF81297 on spatial working memory in aged monkeys. J Pharmacol Exp Ther 283:183-189.

Castner SA, Goldman-Rakic PS (1999) Long-lasting psychotomimetic consequences of repeated low-dose amphetamine exposure in rhesus monkeys. Neuropsychopharmacology 20:10-28.

Castner SA, Williams GV, Goldman-Rakic PS (2000) Reversal of antipsychotic-induced working memory deficits by short-term dopamine $D_{1}$ receptor stimulation. Science 287:2020-2022.

Cools R, Stefanova E, Barker RA, Robbins TW, Owen AM (2002) Dopaminergic modulation of high-level cognition in Parkinson's disease: the role of the prefrontal cortex revealed by PET. Brain 125:584-594.

Criswell H, Mueller RA, Breese GR (1989) Priming of $\mathrm{D}_{1}$-dopamine recep- 
tor responses: long-lasting behavioral supersensitivity to a $\mathrm{D}_{1}$-dopamine agonist following repeated administration to neonatal 6-OHDA-lesioned rats. J Neurosci 9:125-133.

Criswell H, Mueller RA, Breese GR (1990) Long-term $\mathrm{D}_{1}$-dopamine receptor sensitization in neonatal 6-OHDA-lesioned rats is blocked by an NMDA antagonist. Brain Res 512:284-290.

Davidson M, Harvey PD, Bergman RL, Powchik P, Kaminsky R, Losonczy MF, Davis KL (1990) Effects of the D-1 SKF-38393 combined with haloperidol in schizophrenic patients. Arch Gen Psychiatry 47:190-191.

de Keyser J, de Backer JP, Vauquelin G, Ebinger G (1990) The effect of aging on the $\mathrm{D}_{1}$ dopamine receptors in human frontal cortex. Brain Res 528:308-310.

El-Ghundi M, Fletcher PJ, Drago J, Sibley DR, O'Dowd BF, George SR (1999) Spatial learning deficit in dopamine $\mathrm{D}_{1}$ receptor knock-out mice. Eur J Pharmacol 383:95-106.

Enborg ME, Ma SY, Mufson EJ, Levey AI, Taylor MD, Brown WD, Holden JE, Kordower JH (1998) Age-related declines in nigral neuronal function correlate with motor impairments in rhesus monkeys. J Comp Neurol 401:253-265.

Giardina WJ, Williams M (2001) Adrogolide HCl (ABT-431; DAS-431), a prodrug of the dopamine $\mathrm{D}_{1}$ receptor agonist, A-86929: preclinical pharmacology and clinical data. CNS Drug Rev 7:305-316.

Goldberg TE, Bigelow LB, Weinberger DR, Daniel DG, Kleinman JE (1991) Cognitive and behavioral effects of the coadministration of dextroamphetamine and haloperidol in schizophrenia. Am J Psychiatry 148:78-84.

Goldman-Rakic PS, Brown RM (1981) Regional changes in monoamines in cerebral cortex and subcortical structures of aging rhesus monkeys. Neuroscience 6:117-187.

Harada N, Nishiyama S, Satoh K, Fukumoto D, Kakiuchi T, Tsukada H (2002) Age-related changes in the striatal dopamine system in the living brain: a multiparametric study in conscious monkeys. Synapse 45:38-45.

Henby SE, Trojanowski JQ (2003) Neuron-specific age-related decreases in dopamine receptor mRNAs. J Comp Neurol 456:176-183.

Kalivas PW, Stewart J (1991) Dopamine transmission in the initiation and expression of drug and stress-induced sensitization of motor activity. Brain Res Brain Res Rev 16:223-244.

Levy F, Farrow M (2001) Working memory in ADHD: prefrontal-parietal connections. Current Drug Targets 2:347-352.

Lezcano N, Mrzljak L, Eubanks S, Levenson R, Goldman-Rakic P, Bergson C (2000) Dual signaling regulated by calcyon, a $D_{1}$ dopamine receptor interacting protein. Science 287:1660-1664.

Lidow MS, Goldman-Rakic PS (1994) A common action of clozapine, haloperidol, and remoxipride on $\mathrm{D}_{1}$ - and $\mathrm{D}_{2}$-dopaminergic receptors in the primate cerebral cortex. Proc Natl Acad Sci USA 91:4353-4356.

Lidow MS, Williams GV, Goldman-Rakic PS (1998) The cerebral cortex: a case for a common site of action of antipsychotics. Trends Pharmacol Sci 19:136-140.

Ma SY, Ciliax BJ, Stebbins G, Jaffar S, Joyce JN, Cochran EJ, Kordower JH, Mash DC, Levey AI, Mufson EJ (1999) Dopamine transporterimmunoreactive neurons decrease with age in the human substantia nigra. J Comp Neurol 409:25-37.

Muller U, von Cramon Y, Pollman S (1998) $D_{1}$ - versus $D_{2}$-receptor modulation of visuospatial working memory in humans. J Neurosci $18: 2720-2728$.

Naoi M, Maruyama W (1999) Cell death of dopamine neurons in aging and Parkinson's disease. Mech Ageing Dev 111:75-178.

Nieoullon A (2002) Dopamine and the regulation of cognition and attention. Prog Neurobiol 67:53-83.

Pierce RC, Born B, Adams M, Kalivas PW (1996) Repeated intra-ventral tegmental area administration of SKF-38393 induces behavioral and neu- rochemical sensitization to a subsequent cocaine challenge. J Pharmacol Exp Ther 278:384-392.

Pollack AE, Yates TM (1999) Prior $\mathrm{D}_{1}$ dopamine receptor stimulation is required to prime $\mathrm{D}_{2}$-mediated striatal Fos expression in 6-hydroxydopamine-lesioned rats. Neuroscience 94:505-514.

Puri SK, Volicer L (1977) Effect of aging on cyclic AMP levels and adenylate cyclase and phosphodiesterase activities in the rat corpus striatum. Mech Ageing Dev 6:53-58.

Rinne JO, Lonneberg P, Marjamaki P (1990) Age-dependent decline in human brain dopamine $D_{1}$ and $D_{2}$ receptors. Brain Res 508:349-352.

Rinne JO, Portin R, Ruottinen H, Nurmi E, Bergman J, Haaparanta M, Solin O (2000) Cognitive impairment and the brain dopaminergic system in Parkinson disease: $\left[{ }^{18} \mathrm{~F}\right]$ fluorodopa positron emission tomographic study. Arch Neurol 57:470-475.

Robinson TE, Becker JB (1986) Enduring changes in brain and behavior produced by chronic amphetamine administration: a review and valuation of animal models of amphetamine psychosis. Brain Res 396:157-198.

Robinson TE, Kolb B (1999) Alterations in the morphology of dendrites and dendritic spines in the nucleus accumbens and prefrontal cortex following repeated treatment with amphetamine and cocaine. Eur J Neurosci 11:1598-1604.

Sandhu SK, Bhardwaj SK, Sharma P, Kaur G (2001) Alterations in signal transduction cascade in young and adult rat brain and lymphocytes. Brain Res Bull 54:513-520.

Sawaguchi T, Goldman-Rakic PS (1991) $\mathrm{D}_{1}$ dopamine receptors in prefrontal cortex: involvement in working memory. Science 251:947-950.

Sax KW, Strakowski SM (1998) Enhanced behavioral response to repeated D-amphetamine and personality traits in humans. Biol Psychiatry 44:1171-1177.

Schneider JS, Sun ZQ, Roeltgen DP (1994) Effects of dihydrexidine. A full D-1 receptor agonist on delayed response performance in chronic low dose MPTP-treated monkeys. Brain Res 663:140-144.

Shiosaki K, Jenner P, Asin KE, Britton DR, Lin CW, Michaelides M, Smith L, Bianchi B, Didomenico S, Hodges L, Hong Y, Mahan L, Miller T, Nikkel A, Stashko M, Witte D, Williams M (1996) ABT-431: the diacetyl prodrug of A-86929, a potent and selective dopamine $\mathrm{D}_{1}$ receptor agonist: in vitro characterization and effects in animal models of Parkinson's disease. J Pharmacol Exp Ther 276:150-160.

Siddiqi Z, Kemper TL, Killiany R (1999) Age-related neuronal loss from the substantia nigra-pars compacta and ventral tegmental area in the rhesus monkey. J Neuropathol Exp Neurol 58:959-971.

Stewart J, Vezina P (1989) Microinjections of Sch-22390 into the ventral tegmental area and substantia nigra pars reticulata attenuate the development of sensitization to the locomotor activating effects of systemic amphetamine. Brain Res 495:401-406.

Vezina $\mathrm{P}$ (1996) $\mathrm{D}_{1}$ dopamine receptor activation is necessary for the induction of sensitization by amphetamine in the ventral tegmental area. J Neurosci 16:2411-2420.

Volkow ND, Gur RC, Wang GJ, Fowler JS, Moberg PJ, Ding YS, Hitzemann R, Smith G, Logan J (1998) Association between decline in brain dopamine activity with age and cognitive and motor impairment in healthy individuals. Am J Psychiatry 155:344-349.

Wang Y, Chan GL, Holden JE, Dobko T, Mak E, Schulzer M, Huser JM, Snow BJ, Ruth TJ, Calne DB, Stoessl AJ (1998) Age-dependent decline in dopamine $\mathrm{D}_{1}$ receptors in human brain: a PET study. Synapse 30:56-61.

Welsh K, Butters N, Hughes J, Mohs R, Heyman A (1991) Detection of abnormal memory decline in mild cases of Alzheimer's disease using CERAD neuropsychological measures. Arch Neurol 48:278-281.

Williams GV, Goldman-Rakic PS (1995) Modulation of memory fields by dopamine $\mathrm{D}_{1}$ receptors in prefrontal cortex. Nature 376:572-575. 